\title{
Assessment of heavy metals in fish species and some physico-chemical parameters of Oguta lake, Oguta, Imo state, Nigeria
}

\begin{abstract}
This study was carried out to investigate some physico-chemical parameters, and also to examine Nickel, Lead, Manganese, and Copper from Gill, liver, and fillet of three selected fin fish species; Oreochromis niloticus, Synodontis clarias, and Hepsetus odoe of the lake to provide information on the human consumption safeties of these fish samples from the lake. Surface water, and fish samples from three stations and fisherman landing site respectively were collected bi-monthly for three months. Surface water temperature, $\mathrm{pH}$, and Dissolved Oxygen were measured in situ, while other parameters were determined according to APHA standard methods. Data were analyzed using descriptive statistics, ANOVA, and Duncan Multiple Range Test (DMRT) at $\alpha_{0.05}$. All the measured physicochemical parameters are within the recommended permissible limit for aquaculture. Copper recorded the highest metal concentration $(1.55 \mu \mathrm{g} / \mathrm{g})$ in the gill of Oreochromis niloticus. Nickel was not detected in all the observed fish species. The mean concentrations of all the metals in the present study were lower than the permissible limits, thus the sampled fish from the lake are generally safe for human consumption.
\end{abstract}

Keywords: Physico-chemical parameters, Human consumption, Permissible limit, and Oguta Lake
Volume 2 Issue 2 - 2018

Ogueri C,Adebayo ET, Nwaiwu VNC

Department of Fisheries and Aquaculture Technology, Federal University of Technology Owerri, Nigeria

Correspondence: Adebayo ET, Department of Fisheries and Aquaculture Technology, Federal University of Technology Owerri, Nigeria, Email: adebayotemitope.et@gmail.com

Received: January 27, 2018| Published: March 08, 2018

\section{Introduction}

Water Contamination has been long reported as the major threat to the aquatic environment due to their toxicity, long time persistence, bioaccumulation and bio-magnifications in the food chain. ${ }^{1}$ The term "heavy metals" refers to any metallic elements, which are relatively of high density, and toxic or poisonous even at low concentration. Heavy metals enter ecosystems from both natural and human sources and get distributed in the organs and tissues of organisms. Whilst some of these metals are essential in trace amounts to living organisms, they may become highly toxic when present in high concentrations. ${ }^{2,3}$ Bioaccumulation in the tissues of organisms has been identified as an indirect measure of the abundance and availability of these metals in aquatic environments, ${ }^{4}$ and the rate of accumulation depends on the ability of the organism to digest the metals, plus the concentration of such metals in the water body. The rate of bioaccumulation also depends on the concentration of the metals in the surrounding sediments, as well as on the feeding habits of the organism. ${ }^{5}$ Aquatic animals can bio-accumulate trace metals in considerable amounts and the metals can remain in their tissues and organs for long periods. ${ }^{6}$ The non-biodegradability and persistent nature of these metals in the environment make them deleterious in the aquatic environment, and consequently to those who depend on aquatic products, including fish, as a source of food. ${ }^{7}$ Fishes are known to bio-accumulate metals and therefore can be used as bio-monitors, also they have the advantage of allowing the comparison of metal concentrations among sites, where water samples are near or below the detection limits of the Atomic Absorption technique ${ }^{7,8}$ Oguta Lake is not only used for agricultural, artisanal fishing, recreational, transportation, and domestic water supply, but the hosting community and the surrounding industries also channeling their waste into the lake, also Adebayo et al. ${ }^{9}$ have also reported high accumulations of some heavy metals in the lake, thus the need for assessment of its heavy metals concentration in the fish organs and fillet.

\section{Materials and methods}

\section{Description of study area}

Oguta Lake is situated in Oguta Local Government Area of Imo State; it constitutes the largest natural Lake in South-eastern Nigeria. It is bounded on Latitudes $05^{\circ} 41^{\prime}$ to $05^{\circ} 44^{\prime} \mathrm{N}$ and Longitudes $06^{\circ} 41^{\prime}$ to $06^{0} 50^{\prime} \mathrm{E}$, with an elevation of $50 \mathrm{~m}$ above sea level (Figure 1). It occupies a surface area ranging between $1.8 \mathrm{~km}^{2}$ and $2.5 \mathrm{~km}^{2}$, a shoreline length of $10 \mathrm{~km}$, and maximum and mean depths of $8.0 \mathrm{~m}$ and $5.5 \mathrm{~m}$ respectively. ${ }^{10}$ It has river Njaba, Utu and Awbuna as the tributaries and empty into River Niger through River Orashi.

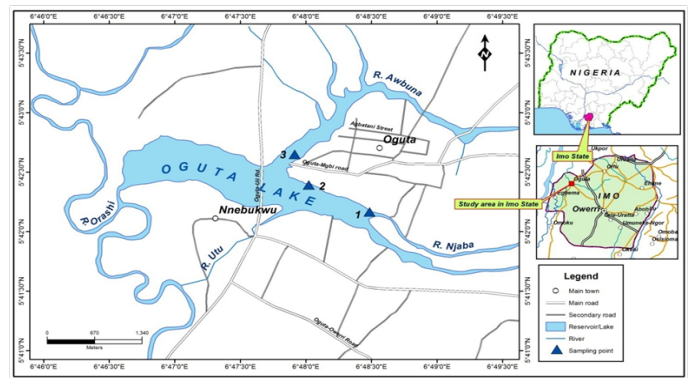

Figure I Map of Oguta Lake showing the sampling stations. (Source: Cartographic unit, Department of Geography, University of Ibadan, Ibadan. February 2016).

\section{Experimental design and Analysis}

Three purposefully sampling stations were selected for water sampling, while fish samples average $50-250 \mathrm{~g}$ and $6-10 \mathrm{~cm}$ were 
collected at the fishermen landing site. Bi-monthly samplings were carried out between the hours of 8.00am-11.00am for three months (March - May, 2016). Temperature, and dissolved oxygen and were measured in situ using Mercury-in-glass Thermometer, and dissolved Oxygen meter (model-5509) respectively. ${ }^{11}$ While surface water samples for Carbon (iv) oxide, total hardness, alkalinity, and ammonium-nitrate were collected in 1L sterile plastic bottle, and transported to the Laboratory, Department of Fisheries and Aquaculture Technology, Federal University of Technology, Owerri, Imo state prior analysis. The Fish organs and tissues were extracted, preserved in the freezer prior its transportation to Central Laboratory, Federal University of Technology Akure, Ondo State, Nigeria in iceblock, for heavy metals analysis. All the analysis was done using a standard analysis method as described by APHA ${ }^{11}$. Descriptive statistics was used to analyze the data. One-way Analysis of Variance (ANOVA) was used in all cases for mean comparisons at 5\% level of significance, using SPSS Version 22.0, while the post hoc Duncan multiple range test was used for mean separation at $p<0.05$.

\section{Results and discussion}

The results of the Physico-chemical parameters of Oguta Lake, are shown in Table 1-3, and Figure 2-4 respectively.

Table I The physico-chemical parameters of Oguta Lake, during the study period

\begin{tabular}{|c|c|c|c|}
\hline Parameter & Mean & $\mathrm{WHO}^{26}$ & NESREA $^{27}$ \\
\hline Temperature $\left({ }^{\circ} \mathrm{C}\right)$ & $27.92 \pm 0.27$ & $30.00-32.00$ & - \\
\hline $\mathrm{pH}$ & $7.64 \pm 0.44$ & $7.00-8.50$ & $6.50-8.50$ \\
\hline Free $\mathrm{CO}_{2}(\mathrm{ppm})$ & $15.75 \pm 1.09$ & $<10.00$ & NS \\
\hline D.O (ppm) & $6.63 \pm 0.62$ & $>5.00$ & Not $<6.0$ \\
\hline $\begin{array}{l}\text { Total Hardness } \\
\text { (ppm) }\end{array}$ & $15.58 \pm 0.69$ & 150.00 & NS \\
\hline Alkalinity (ppm) & $15.08 \pm 2.46$ & 200.00 & NS \\
\hline $\begin{array}{l}\text { Ammonium- } \\
\text { Nitrogen (ppm) }\end{array}$ & $0.33 \pm 0.04$ & & NS \\
\hline $\mathrm{Cu}_{\mathrm{w}}(\mathrm{mg} / \mathrm{L})$ & ND & $<0.50$ & 0.001 \\
\hline$M n_{w}(m g / L)$ & $0.01 \pm 0.01$ & $0.10-0.50$ & NS \\
\hline $\mathrm{Pb}_{w}(\mathrm{mg} / \mathrm{L})$ & ND & - & 0.01 \\
\hline $\mathrm{Cu}_{\mathrm{s}}(\mathrm{mg} / \mathrm{g})$ & $6.53 \pm 1.44$ & - & - \\
\hline$M n_{s}(m g / g)$ & $17.22 \pm 2.77$ & - & - \\
\hline $\mathrm{Pb}_{\mathrm{s}}(\mathrm{mg} / \mathrm{g})$ & $9.58 \pm 2.75$ & - & - \\
\hline
\end{tabular}

NOTE: NS, Not Specified; ND, Not detected

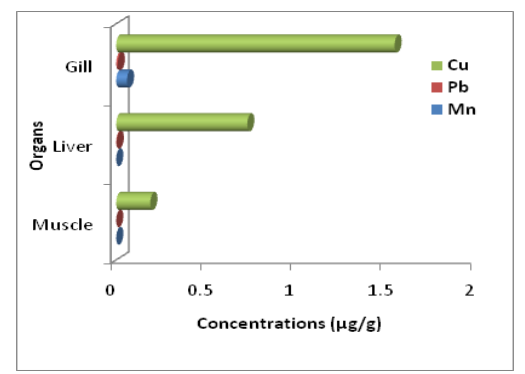

Figure 2 Mean concentrations of Heavy metals in selected organs of Oreochromis niloticus
Table 2 Spatial variation in Physico-chemical parameters of Oguta Lake during the study period

\begin{tabular}{|c|c|c|c|c|}
\hline \multirow{2}{*}{ Parameter } & \multicolumn{3}{|c|}{ Stations } & \multirow{2}{*}{ F-Value } \\
\hline & I & 2 & 3 & \\
\hline Temperature $\left({ }^{\circ} \mathrm{C}\right)$ & $27.13^{b}$ & $27.88^{\mathrm{ab}}$ & $28.75^{\mathrm{a}}$ & 0.024 \\
\hline $\mathrm{pH}$ & $7.45^{\mathrm{a}}$ & $8.50^{\mathrm{a}}$ & $6.98^{\mathrm{a}}$ & 0.389 \\
\hline Free $\mathrm{CO}_{2}(\mathrm{ppm})$ & $15.25^{\mathrm{b}}$ & $12.50^{\mathrm{b}}$ & $19.50^{\mathrm{a}}$ & 0.012 \\
\hline $\begin{array}{l}\text { Dissolved Oxygen } \\
\text { (ppm) }\end{array}$ & $4.23^{b}$ & $7.78^{\mathrm{a}}$ & $7.90^{\mathrm{a}}$ & 0.005 \\
\hline $\begin{array}{l}\text { Total Hardness } \\
\text { (ppm) }\end{array}$ & $15.00^{\mathrm{b}}$ & $13.75^{\mathrm{b}}$ & $18.00^{\mathrm{a}}$ & 0.015 \\
\hline Alkalinity (ppm) & $19.25^{\mathrm{a}}$ & $13.00^{\mathrm{a}}$ & $13.00^{\mathrm{a}}$ & 0.533 \\
\hline $\begin{array}{l}\text { Ammonium- } \\
\text { Nitrogen (ppm) }\end{array}$ & $0.25^{\mathrm{b}}$ & $0.25^{b}$ & $0.50^{\mathrm{a}}$ & 0.012 \\
\hline
\end{tabular}

N.B,Values with the same superscript along same row are not significantly different at $\mathrm{P}<0.05$

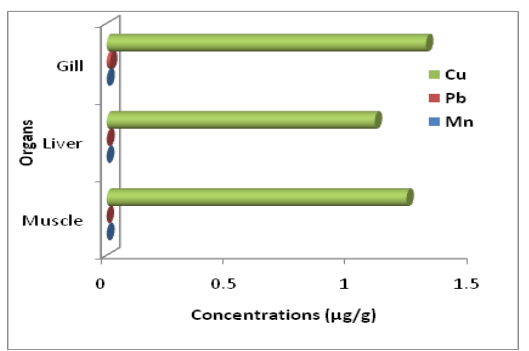

Figure 3 Mean concentrations of Heavy metals in selected organs of Synodontis clarias

Table 3 Correlation coefficient between the physic-chemical parameters of Oguta Lake during the study period

\begin{tabular}{|c|c|c|c|c|c|c|c|}
\hline $\mathrm{NH}_{2-} \mathrm{N}$ & Alkal. & DO & $\mathrm{FCO}_{2}$ & Hard. & Temp. & & \\
\hline Alkal. & & -0.146 & & & & & \\
\hline DO & & 0.188 & -0.385 & & & & \\
\hline $\mathrm{FCO}_{2}$ & & 0.462 & -0.002 & 0.095 & & & \\
\hline Hardness & 0.358 & -0.056 & 0.201 & $0.599 *$ & & & \\
\hline Temp. & & $\begin{array}{l}0.715^{* *} \text { - } \\
0.207\end{array}$ & 0.43 & 0.045 & 0.312 & & \\
\hline $\mathrm{pH}$ & & -0.369 & -0.173 & 0.161 & -0.219 & -0.308 & -0.306 \\
\hline
\end{tabular}

N.B: *, Significant at $\mathrm{P}<0.05 ; * *$, Significant at $\mathrm{P}<0.0$

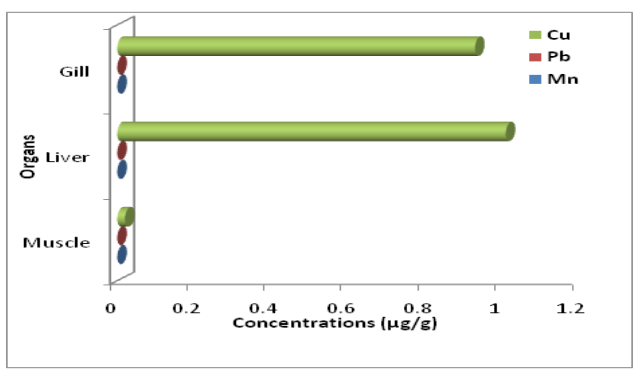

Figure 4 Mean concentrations of Heavy metals in selected organs of Hepsetus odoe

The observed significant variation in surface water temperature, free carbon (iv) oxide, dissolved oxygen, total hardness, and ammonium-nitrate of the current work may have affected the speed 
of one or more of the biochemical reactions, the metabolic rates of the organism, how pollutants interacted with the organism, and other materials in water, as also observed by Ogbuagu et al. ${ }^{3}$ UNEP GEMS $^{12}$ and Akinrotimi et al. ${ }^{13}$ These variations may be related to patterns of water use, weather conditions, water depth, and run-off that brought in different allochthonous materials during the rainfall. Similar observation have been previously reported by Atobatele and Ugwumba ${ }^{14}$ Mustapha ${ }^{15}$ Edward and Ugwumba, ${ }^{16}$ Spaak and Bauchrowitz ${ }^{17}$ and $U s m a n^{18}$ where it was stated that water quality largely regulates the distribution and productivity levels of resident organisms, and that changes in it can alter natural biodiversity. On the other hand, the observed direct correlation between surface water temperature and ammonium-nitrate at $\mathrm{p}<0.01$, and hardness and free carbon (iv) oxide at $p<0.05$ reflects the significantly contributions of these parameters to the recorded variation in the physico-chemical parameters of the lake, and their subsequent enhancement in the solubility of the introduced contaminants. This study further revealed that mean concentration of the observed heavy metals varies with fish species, and the respective organs; as higher mean concentration was recorded in the gills of Oreochromis niloticus and Synodontis clarias.

Accumulation levels in the fish organs and tissue were habit dependent in the current study, with higher accumulations induced by the feeding habit of the fish species. The recorded higher concentration of copper in the gill of $O$. niloticus could be adduced for by this organ being a constant organ and the feeding habit of this species that make it prone to more concentrations of the contaminant, unlike the other species that are carnivores. This agreed with the earlier report of Almajed and Preston ${ }^{19}$ and Yilmaz ${ }^{20}$ who opined that bio-accumulations of heavy metals in fish depends on the fish species, size, age, type of tissue analysed, feeding habit, and the habitat. Though the recorded concentrations in the heavy metals do not exceed FAO, ${ }^{21} \mathrm{MAFF}^{22}$ $\mathrm{EU}^{23}$ and $\mathrm{EC}^{24}$ maximum recommended value $(20-30 \mu \mathrm{g} / \mathrm{g})$ in fish food, but Adebayo et al. ${ }^{9}$ have also reported the exceeding levels in the concentrations of some of these metals in both water and sediment of the lake. This was similar to Kamaruzzaman et al. ${ }^{25}$ report that the accumulation of essential metals in fish are generally higher and more homeostatic than the non-essential metals due to the crucial role played by the essential metals as precursors in most of the enzymatic activities.

\section{Conclusion}

The physico-chemical parameters of the Oguta Lake in Imo State, like any other aquatic ecosystem, is prone to ecological imbalances resulting from both natural and anthropogenic impacts arising from man's quest for the exploitation of natural resources for sustainability and livelihood. The studied fish species in the lake during this study are considered safe for human consumption, since the recorded heavy metals concentration did not exceed the standard limit for aquatic life and drinking water.

\section{Acknowledgement}

We are grateful to the manager of the Oguta Lake Water Cooperation for allowing for this research. Our gratitude also goes to the staff of the research laboratory, Federal University of Technology, Akure, where the analyses were carried out, and Dr Ogbuagu Dike Henry who helped in the statistical analysis.

\section{Conflict of interest}

Author declares there is no conflict of interest

\section{References}

1. Morilla J, Usero J, Cracia I. Heavy metaldistribution in marine sediments from the southwest Coast of Spain. Chemosphere. 2004;55(3):431.

2. Ogbuagu DH, Okoli CG, Emereibeole EI, et al. Trace metals accumulation in biofilms of the upper and middle reaches of Otamiri River in Owerri, Nigeria. Journal of Biodiversity and Environmental Sciences. 2011;1:1926.

3. Ogbuagu DH, Adebayo ET, Ayoade AA, et al. Lead accumulation in and its haematological effects on African catfish Clarias gariepinus. African Journal of Aquatic Science. 2015;40(2):1-6.

4. Kucuksegin FA, Kontas O, Altay E, et al. Assessment of marine pollution in Izmir Bay: nutrient heavy metal and total hydrocarbon concentrations. Environment International. 2006;3(1):41-51.

5. Ishaq SE, Rufus S, Annune PA. Bioaccumulation of heavy metals in fish (Tilapia Zilli and Clarias Gariepinus) organs from River Benue, North-central Nigeria. Pakistan Journal of Analytical and Environmental Chemistry. 2011;12(1\&2):25-31.

6. Oberholster PJ, Myburgh JG, Ashton PJ, et al. Bioaccumulation of aluminium and iron in the food chain of Lake Loskop, South Africa. Ecotoxicology and Environmental Safety. 2012;75(1):134-141.

7. Kakulu SE, Osibanjo O. Trace heavy metal pollution status in sediments of Niger Delta area. Journal of Chemical Society of Nigeria. 1988;13:911 .

8. Saha N, Zaman MR. Evaluation of possible health risks of heavy metals by consumption of foodstuffs available in the central market of Pajshahi City, Bangladesh. Environ monit Assess. 2012;185(5):3867-3878.

9. Adebayo ET, C-Oluwatosin TJ, Nneji PC. Limnological assessment of heavy metals concentration in water and sediment of Oguta Lake, Southeastern Nigeria, Nigeria. International Journal of Innovative Studies in Aquatic Biology and Fisheries (IJISABF). 2017;3(3):18-22.

10. Nfor BN, Akaegbobi IM. Inventory of the Quaternary Geology and the Evolution of the Oguta Lake, in Southeastern Nigeria. World Journal of Engineering and Pure and Applied Sci. 2012;2(1):1-6.

11. American Public Health Association (APHA). Standard Methods for the Examination of Water and Wastewater. $20^{\text {th }}$ edition. APHA/AWWA/WEF: Washington DC;1998.

12. UNEP GEMS (United Nations Environmental Programme Global Environment Monitoring System). Water quality for ecosystem and human health. UNEP GEMS/Water Programme, Ontari; 2006.

13. Akinrotimi OA, Ansa EJ, Owhonda KN, et al. Effects of transportation stress on haematological parameters of blackchin tilapia Sarotherodon melanotheron. Journal of Animal and Veterinary Advances. 2007;6:841845 .

14. Atobatele OE, Ugwumba OA. Seasonal Variation in the Physico-chemistry of a Small Tropical Reservoir (Aiba Reservoir, Iwo, Osun, Nigeria). African Journal of Biotechnology. 2008;7(12):62-171.

15. Mustapha MK. Phytoplankton assemblage of a small, shallow, tropical African reservoir. Int J Trop Biol. 2000;57(4):1009-1025.

16. Edward JB, Ugwumba AAA. Physico-Chemical Parameters and Plankton Community of Egbe Reservoir, Ekiti State, Nigeria. Research Journal of Biological Sciences. 2010;5(5):56-367. 
17. Spaak P, Bauchrowitz M. Environmental influences and plankton dynamics. Eawag News (Swiss Federal Institute of Aquatic Science and Technology). 2010;69e:25-27.

18. Usman H. Determination of physico-chemical parameters and plankton composition of wawan-rafi lake in kazaure, nigeria. Ahmadu Bello University, Zaria: M.sc thesis, Department of Biological Science; 2015.

19. Almajed N, Preston M. An assessment of the total and methyl mercury content of zooplankton and fish tissue collected from Kuwait territorial waters. Ma Pollut Bull. 2000;40(4):298-307.

20. Yilmaz AB. Comparison of heavy metal levels of grey mullet (Mugil cephalus) and sea bream (Sparus aurata) caught in Iskenderum Bay (Turkey). Turk J Vet Anim Sci. 2005;29:257-262.

21. Food and Agriculture Organization-FAO. Compilation of legal limits for hazardous substances in fish and fishery products. FAO Fisherycircular. 1983;464:5-100.

22. Ministry of Agriculture, Fisheries and Food-MAFF. Monitoring and surveillance of non- environment and activities regulating the disposal of waters at Sea, 1997. In Aquatic Environment Monitoring Report No. 52. Lowestoft, UK Center for Environment, Fisheries and Aquaculture Science; 2000.

23. EU. Commission Regulation as regards heavy metals, Directive, 2001/22 EC, No: 466. The Commission of The European Communities; 2001.

24. European Commision. Commission Regulation (EC) No. 78, amending Regul;ation (EC) No. 466/2001 as regards heavy metals L 16/43-45.2005. p. 59-61.

25. Kamaruzzaman YB, Ong CM, Rina ZS. Concentration of Zinc, Copper, and Lead in some selected marine fishes of the Pahang coastal waters, Malaysia. American Journal of Applied Sciences. 2010;7(3):309-314.

26. World Health Organization (WHO). Guidelines for drinking water quality. $3^{\text {rd }}$ edition. Geneva: Health criteria and supporting information; 2008.

27. NESREA. National Environmental (Surface and Groundwater Quality Control) Regulations. Federal Republic of Nigeria Official Gazette No. 49. $2011 ; 98$ 